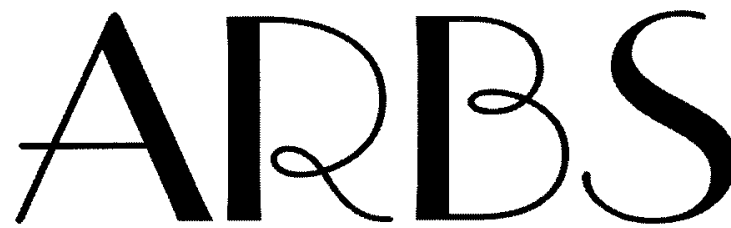

L MENNA-BARRETO

Departamento de Fisiologia e Biofísica, Instituto de Ciências Biomédicas, Universidade de São Paulo, BRAZIL

\title{
Human Chronobiology
}

\section{Contents}

Abstract

Clocks \& Rhythms

A Wide Spectrum

Homeostasis Revisited

Internal Temporal Order

Synchronization

Social Cycles

From Womb to Tomb

Individual Differences

Research-History

Eliminating External Timing

Windows in Time

Individual Times?

Chrono-Health

Breaking Cloks

Currently Published Periodicals on Chronobiology

Glossary of Chronobiology

Internet Sites on Chronobiology

References

- Luiz Menna-Barreto, Grupo Multidisciplinar de Desenvolvimento e Ritmos Biológicos, Departamento de Fisiologia e Biofísica, Instituto de Ciências Biomédicas, Universidade de São Paulo, Brasil.

E-mail: menna@fisio.icb.usp.br. Av. Lineu Prestes 1524 - CEP 05508-900 - São Paulo - SP, BRASIL. 
Brief introduction to Chronobiology, followed by considerations on the landmarks of this new field of biological science, focussed on its implications on human physiology and behaviour, as well as its applications to medicine and social organization. Periodicals, Internet sites and relevant literature dedicated to Chronobiology are included to help newcomers.

Koy-wordss biological clocks, biological rhythms, chronobiology.

\section{Clocks \& Rhytms}

Humanity has been oscillating since its origins, following both environmental cycles and obeying bodily urges such as hunger or sleep. Biological rhythms, or regular fluctuations of body functions, have long been recognized, in empirical terms, in all living organisms, but it was not until the beginning of the $18^{\text {th }}$ century that the question of the determination of rhythmicity was raised in what may be understood as the birth of modern chronobiology. Jean Jacques d'Ortous de Mairan, a French astronomer, showed that a plant kept in isolation from the natural environment, in constant lighting conditions, maintained its periodic leaf movements approximately coinciding with the day/night cycle (Moore-Ede et al., 1982).

Almost three centuries later, we repeat the basic procedure, tempora] isolation, in order to witness the ticks of what came to be recognized as the biologica] clocks (Garfield, 1988a\&1988b). The expression "biological clock" is an apt choice for producing surprise and thus became popular; nevertheless, it implies discrete structures with "cogs and wheels" which may not necessarily be the case. A much better expression is "timing system", opening room for functional circuits linking different parts of the organisms (Moore, 1999).

Biological rhythms, in a strict sense, are generated endogenously anc adjusted to environmental cycles by organic timing systems (Aschoff, 1976). In a broader sense, biological rhythms may be defined as all regular oscillations expressec by an organism, or population of organisms, independently of the endogenous or exogenous origin of the oscillation.

Examples of biological rhythms in this broader sense:

1) respiratory and cardiac cycles do not show entrainment tc environmental cycles although they may be modulated by external stimuli;

2) the 7-day rhythm represented by the human week might be determined endogenously (Halberg, 1983\&1985; Aveni, 1995), but not necessarily so (Zerubavel, 1985).

Unless otherwise stated, we will use the expression "biological rhythms' in this second, broader sense. Moreover, biological rhythms may refer to periodicities observed in a species but not in the individual - gestation, puberty, menopause and the life cycle itself, are examples of such rhythms. 


\section{A Wide Spectrum}

There is a wide spectrum of biological rhythms, from fast oscillations in pacemaker neurons (Minors \& Waterhouse, 1981) to seasonal changes in hormone secretion (Aschoff, 1981). The parameter frequency has been adopted for the classification of biological rhythms as circadian (one cycle per $24 \mathrm{~h}$ ); ultradian (faster rhythms) and infradian (slower rhythms). (Halberg, 1959). Rhythms which are synchronized to external cycles are referred to as "circarhythms" (Aschoff, 1979), such as circadian, circalunar, circatidal, circannual - the prefix circa allowing for a range along which the frequency may vary, e.g. from one cycle each 20 to $28 \mathrm{~h}$ for the circadian.

A biological rhythm may be approximately depicted by a cosine curve in which we identify the amplitude of the oscillation, its phases and period, although other formats may express a rhythm with better accuracy, such as a triangular form depicting the pulsatile episodes of hormone plasma concentration.

In all cases it is clear that the linear representation of the dynamics of a biological variable as a mean omits its obvious time-dependent nature, thus inviting us to reconsider some dogmas of normality, such as usual timeless interpretation of normal temperature as a straight line around $36.5^{\circ} \mathrm{C}$. The $\pm 0.5^{\circ} \mathrm{C}$ that usually follows that figure, although admitting variability, does not imply the now obvious "time-ofday" effect. $35.5^{\circ} \mathrm{C}$ at $05: 00 \mathrm{~h}$ is normal as is $37.5^{\circ} \mathrm{C}$ around $18: 00 \mathrm{~h}$ in a diurnallyactive, healthy individual, and this variation is not entirely due to direct posture, exercise, or metabolic effects on thermoregulation, since the fluctuation also happens in individuals under constant conditions such as temperature and illumination, fed intravenously in a continuous manner (Minors \& Waterhouse, 1981).

\section{Homeostasis Revisited}

The invitation to revisit classical data may be one the most relevant contributions of Chronobiology to contemporary biological thinking.

Homeostasis may vary, said Martin Moore-Ede (1986) to the select audience at the 1986 meeting of the American Physiological Society, suggesting the adjective "predictive" rather than "reactive" to qualify homoestasis. Alternatively, rheostasis, or "the physiology of change", in the words of Nicholas Mrosovsky (1990), may be a more powerful key, able to encompass a wider range of phenomena, which, until recently, were shown as limited to closed systems.

Another expression, homeodynamics, is discussed by Goodwin (1997), who advocates a model composed of chaotic generators and several interacting oscillators, a system able to cope with a changing environment. 


\section{Internal Temporal Order}

Cortisol secretion peaks about an hour before we wake-up, which coincides with the rise of core temperature; by the end of the day core temperature starts declining after reaching its peak; in a couple of hours sleep comes followed by increased secretion of growth hormone, and so on (Copinschi et al., 1999). We are facing what has been named by Moore-Ede and Sulzman (1981) "Internal Temporal Order". Physiological functions succeed each other more or less regularly, some of them causally linked, such as in the hipothalamo-pituitary-adrenal axis of hormone control, some of them only temporally coupled such as the Growth Hormone-Slow Wave Sleep (Van Cauter et al., 1998).

Maintenance of the Internal Temporal Order equals good health condition, as the adverse effects on health of "jet lag" or shiftwork unambiguously demostrate (Folkard et al., 1986). Since the demonstrations of Dorothy Krieger (1979) among others, we have sufficient reasons to assume that the presence of a neurotransmitter at a synapse is not the only condition for its efficacy - the readiness of the membrane plays the other essential role; the parallel controls of neurotransmitter liberation and post-synaptic membrane configuration need a temporal link in order to function properly - and this is granted by the coordinate functioning of the timing systems.

Phase maps of a multitude of physiological variables have been proposed by several authors (Moore-Ede et al., 1982).

Internal Temporal Order refers to more or less stable phase relationships between variables in an individual organism. External relationships between individual and environment, social interactions included, may constitute what may be called an External Temporal Order. The usefulness of such a concept has yet to be put to the test.

\section{Synchronization}

Entrainment or synchronization of human biological rhythms to environmental cycles has been studied mostly in the circadian range; circadian rhythms are readily observable as well as their synchronizing environmental cues.

Jurgen Aschoff (1954) coined the word zeitgeber (german word for "time giver") which is now widely employed together with entrainning or synchronizing agent. It is worth noting that the loose usage of such terms has led to a confusion which may be charactized by the expressions "light as a zeitgeber", "mother as a zeitgeber", etc.

The confusion resides in the now well-known fact that light per se (as any other environmental cue) shows distinct and even opposite effects on the circadian timing system of organisms, including humans.

In the middle of the day light has no effect; in the beginning of the night light produces a phase advance (the circadian system runs faster) whereas by the 
end of the night the same light slows down the system. This phenomenon is usually depicted in a graphic form known as a phase response curve (PRC). There are atlases of PRC's for several species readily available in the Internet, see Internet Chronobiology sites list at the end of this review.

\section{Social Cycles}

Social cycles, comprising working and leisure hours, have been suggested to be the most powerful if not the only zeitgeber for humans (Aschoff \& Wever, 1976). Relatively recent studies have demonstrated important effects of light/dark cycles upon human circadian rhythmicity, including phase advances and delays of the core temperature rhythm (Shanahan et al., 1997). In the last section of this review we will come back to these effects of the LD cycle, as they have been employed in clinical studies on depression and re-entrainment of shiftworkers and airplane crews.

The fact that social cycles do entrain circadian rhythms raises the issue of the range of stimuli (nature of the time cues) able to synchronize humans. A common wristwatch may be a suitable example of the complex nature of the social time cue. Although two persons may see the same hour on a watch, the conditioned effects on each individual may lead to opposite changes in their behaviour and underlying physiological adjustments.

Regularly spaced sounds of a gong signalling moments for urine collection were able to synchronize circadian rhythms of an isolated individual under otherwise constant conditions (Aschoff \& Wever, 1976). One can predict sunrise and sunset as producing distinct synchronizing consequences in a farmer when compared to his urban cousin, and so on.

Not only human rhythms are entrained by social cycles, as has been elegantly demonstrated by Mrozovsky et al. (1989) and his pulse of female synchonizing male hamsters. Furthermore, a zeigeber effective in an adult may not produce any synchronizing effect on an infant or on an elderly person.

\section{From Womb to Tomb}

Human biological rhythmicity changes with age (Davis, 1981). Intrauterine rhythms in the human fetus (rest/activity) have been described and are assumed to be synchronized, if not "exogenously" determined by the mother (Weaver \& Reppert, 1989).

Birth can be considered a physiological revolution in several aspects, temporal regulation being one of the most prominent - time cues change in nature and mode of acting on the body.

During his first days a newborn baby shows practically only ultradian rhythms, the most conspicuous being the 3-4h sleep/wake cycle (Meier-Koll, 1979). The following weeks witness the increasing presence of circadian rhythmicity, with 
the remarkable characteristic of large individual differences in the age from the seconc week to the eighth (Menna-Barreto et al., 1993).

The picture we are able to draw is of a gradual coalescence of ultradiar into a circadian pattern as in the sleep/wake changing pattern. Family routines compose the temporal setting during infancy and represent the first markedly externa impositons upon the timing system of the developing individual with which he wil learn to negotiate (Tomioka \& Tomioka, 1991).

School life is another "time-mark", when what may be called "the tempora range" is enlarged and enriched by new social interactions. New temporal challenges may come up such as changes in school schedules and increasing constraints or time available for sleep; those challenges proceed into adolescence with the wel recognized restriction-extension pattern of the sleep/wake cycle - shorter sleer episodes during the week alternate with longer sleep episodes during the weekends (Andrade et al., 1993; Bearpark \& Michie, 1987). This pattern can be associated with the complaints of excessive daytime sleepiness acompanying puberty, although hormonal changes seem to play an important role as well, promoting a phase delay in circadian rhythms at that age. The effects of this phase delay - delayed sleep onset and delayed wake-up time - associated with the new social demands, compose a wel] known setting for temporal struggles between teenagers and parents (Carskadon et al., 1980).

Adults, especially in industrialized urban areas, play with their biologica] timing systems, scheduling work at irregular hours, extending wakefulness, eating at odd times, and so on.

Awareness of the consequences of such tampering with our timing systems has been increasing since the demonstration of incidence of mistakes in radar-signal detection by navy crews submitted to non-24h work/rest cycles (Colquhoun et al., 1996).

Biological rhythmicity in the elderly is known to show decreases both in amplitude and strength of the circadian component (Monk et al., 1992). Those decreases may be a natural step in ontogeny, due to cell death in the timing systems of the Central Nervous System, weakening of zeitgeber action, decreased coupling between parts of the timing system and/or effector mechanisms. Alternatively, the decreases might represent secondary effects of diseases or attenuation of other functional capacities.

Very active ạnd healthy elderly do not necessarily show the decrease in amplitude and strength mentioned above (Touitou et al., 1997; Ceolim \& MennaBarreto, 1999).The challenge here is to link the aging process to the already known components of the timing system, such as the suprachiasmatic nuclei of the anterior hypothalamus and the genes controlling aspects of circadian rhythmicity which are being identified contemporaneously (Cashmore et al., 1999; Gekakis et al., 1998). Genetic manipulation of life-cycle duration seems to be the next step ahead, since molecular biology is paving the way into the fruit fly and the mouse timing systems 
(Wilsbacher \& Takahashi, 1998). It must be stressed however that changes in life expectancy call for associated better quality of life, which includes wiser time management. In this respect, human chronobiology may offer relevant contributions in the near future.

\section{Individual Differences}

Larks, or morning people, and owls, evening types, are part of our everyday experience with a striking characteristic concerning the variability of phase allocation of ciradian rhythmicity in humans. Evidence points to genetic determination of the "chronotype" and the variability of types itself suggests either a loose control by selective forces or an adaptive advantage for the species, able to occupy a larger portion of the $24 \mathrm{~h}$ cycle. Chronotypes may identified by specially-devised questionnaires (Horne \& Östberg, 1976).

Short and long sleepers were defined in the seventies by Webb (1979), being an easily recognizable individual difference in sleep-duration preference. Sleepduration preferences may be assessed by measuring the sleep phase along two to three consecutive weeks in a situation as free of temporal constraints as can be devised.

Attempts to associate chronotype or sleep duration type to differences in performance do not show any consistent result, although there is a strong social prejudice against evening types and long sleepers, as contrasted to morning active and short sleeping types. Chronobiology might be of help in clarifying and perhaps changing this widespread prejudice.

\section{Research - History}

Research on human rhythms started in the $17^{\text {th }}$ century, when Sartorius built a floating room, suspended over strings where he slept and spent most of his waking time. Body weight circadian and monthly rhythms were thus detected. In the $18^{\text {th }}$ century, Virey wrote a doctoral thesis on the fluctuations of temperature as a marker of health and disease, thus anticipating research performed in the second half of the $20^{\text {th }}$ century (Reinberg \& Smolensky, 1983).

Jurgen Aschoff in Germany, Franz Halberg in the United States, and Alain Reinberg in France are the immediate fathers of contemporary chronobiology, all of them with important contributions on human rhythms. Aschoff is famous for his isolation-unit experiments in Andechs, Germany, summarized by Wever (1979); Franz Halberg in Minnesota produced an enormous amount of data and coined most of the chronobiological jargon in use today; to Alain Reinberg we owe the beginnings of chronopharmacology, especially the asthma studies. Contemporary chronobiology is marked by molecular biology and new possibilities of intervention in human rhythmicity represented by light therapies and melatonin studies (Wilsbacher $\&$ Takahashi, 1998; Arendt, 1998; Morin, 1999; Cashmore et al., 1999). 


\section{Eliminating External Timing}

Isolation experiments in humans were indeed crucial for the recognition of the relevance of biological rhythmicity. The demonstration of persistance of biological rhythms in the absence of external cycles, associated with the identification of structures in the CNS of mammals participating in the generation of circadian rhythms, made possible the scenario for the recognition of chronobiology as a scientific field (Aschoff, 1960).

In isolation studies humans show free-running rhythms in sleep/wake states, core temperature, urine volume and composition, and hormone secretion, among others. Those studies have been conducted in caves or in specially-built facilities called Isolation Units (Minors \& Waterhouse, 1981). Although extremely important for the demonstration of the endogenous determination of biological rhythms, it is important to draw attention to two points: 1) Temporal isolation is an artificial environment, especially for humans; 2) Biological rhythms tend to show disruption after long periods of isolation, which may be the consequence of the artificial environment.

Free-running rhythms never match 24 hours: in humans they are slower than synchronized rhythms, somewhere in the vicinity of $24.3 \mathrm{~h}$; in other species they may be faster or slower. Human free-running rhythms were at first thought to be slower, with a period of around 25h (Wever, 1979); but recent evidence showed that the presumed values should be corrected in order to account for a phenomenon called internal masking (Minors \& Waterhouse, 1989). Constant routine protocols were devised with subjects kept awake for 36 consecutive hours (Minors \& Waterhouse, 1989), in an attempt to control masking.

In order to prevent errors eventually induced by isolation, demasking or purification protocols are now being employed to edit data collected in the field. An example of this procedure: in an investigation on the effects of abrupt phase changes (someone starting to work night shifts) where core-temperature data are collected with electronic probes and recorded every minute, values are corrected by a positive factor when the individual is asleep or resting and by a negative factor when the individual is active (Minors \& Waterhouse, 1989) in an attempt to control masking.

\section{Windows in Time}

Timing of data collection has always been a central issue in questions regarding chronobiology (Halberg, 1959). Not only the definition of the moment of data collection, but also the interval and number of "visits" to the biological system under study, must be taken into consideration. It is generally accepted a minimum of four data points per cycle investigated for at least three full cycles (Minors \& Waterhouse, 1988).

Longitudinal designs are recommended as a means to circumvent interindividual variability, although care must be taken in order to minimize 
interferences of the data collection procedure over the rhythm under study. A clear example of this negotiation is the design of sleep/wake cycle studies: one can either rely on polysonographic data and have the subjects sleep in the lab for two or three days or trust the subject's adherence to a protocol requiring maintenance of sleep logs for two to three consecutive weeks. Depending on the question one is asking, the discomfort of the polysonography wiring or the errors involved in self-measurements may be tolerated.

\section{Individual Times?}

The problem of individual differences may be approached by sychronizing subjects to the same time cues; this may reduce variability but may be technically difficult; moreover it does not account for individual characteristics such as morningness / eveningness. Consider a morning type whose core temperature peaks at 15:00h and an evening type with a peak at 20:00h; mean temperature peak at the midpoint 17:30h may be misleading information, although both of them may be perfectly synchronized to the same $24 \mathrm{~h}$ routine. The solution here resides in choosing a distinctive phase of marker rhythm, generally the phase when core temperature reaches its highest (acrophase) or its lowest (bathyphase) values as time reference, and adjusting the phases of different subjects (Minors \& Waterhouse, 1981). Cortisol and melatonin peak plasma concentrations have been used as marker rhythms recently (Copinschi et al., 1999).

Quite another problem is the variability in values, not in time. Suppose two healthy individuals whose heart rate oscillates between 60 and $100 \mathrm{bpm}$, in one case, and 40 to $80 \mathrm{bpm}$ in the other. Although oscillating in distinct ranges, the temporal patterns may be markedly similar. Since the relevant question in chronobiological studies is the temporal pattern of the variables, their absolute values may vary between subjects as long as the amplitude of the oscillations remains within similar ranges.

Classical reports on human biological rhythms relied mostly on direct visual inspection of time series plotted along a time axis, generally with the size of the rhythm under investigation. Thus, a circadian rhythm appears as a vertical sequence of consecutive days, plotted as continuous or discrete events on a $24 \mathrm{~h}$ time axis. Very often the abcissae are extended to $48 \mathrm{~h}$ in what is called "double plot" to allow inspection of transient phenomena or non-24h rhythms such as those in freerunning conditions.

Most of the statistical analyses consisted of comparisons of mean diurnal against nocturnal values - a rhythm was said to exist when the difference between the means became significant (Hellbrugge, 1960). A step ahead was taken when analyses of variance comparing several data points were performed - the independent variable being the time points of data collection. Post-hoc analyses are necessary for comparisons between particular data points. 
Spectral analyses based on Fourier Transforms are a powerful resource for the detection of regular oscillations in a time series, with the clear advantage of identifying composition of frequencies (DePrins \& Malbecq, 1983).

The Cosinor technique, especially devised for the detection of biological rhythms, in its early and classical version, allowed the analysis of a single frequency (Nelson et al., 1979). In biological systems the simultaneous presence of periodicities of different frequency are more of a rule than an exception - besides the more obvious circadian component, biological rhythms generally show modulations by both infradian and ultradian components (Tsai et al., 1989). Other tools have been proposed (Sokolov \& Bushell, 1978; Minors \& Waterhouse, 1981). There are new softwares especially designed for the processing and analyses of biological rhythms, such as "El Temps", produced by Antoni Diez-Noguera of the University of Barcelona and available at: http://www.ub.es/dpfisiv/soft/ElTemps.

Ultradian rhythms have been studied with the help of the new tools of non-linear dynamic systems, which seem to be appropriate for the multidetermined biological functions (Glass \& Mackey, 1988). The idea of a stable system, showing recurrent states along a regular cycle, is certainly familiar to chronobiologists. Furthermore, this approach is ready to accept disturbances elicited by external signals given at certain points in time, disrupting the former cycle and eventually rebuilding it at another point, which is again what chronobiologists see in real life.

Chronobiology's contribution to research resides not only on the unveiling of oscillations in all biological systems, but also in calling the attention of investigators to the time and frequency domains of the phenomena under scrutiny. Fundamental concepts such as homeostasis are being reanalysed - homeodynamics (Goodwin, 1997) or rhoestasis (Mrozovsky, 1990) might become more suitable as a general principle of living systems, in the sense that they emphasize its oscillatory character. Collecting data in these days may thus be described as opening windows in time, according to protocols designed to take oscillations into account. Moreover, technology now offers several possibilities for automatic monitoring, recording, and transference of data (Miles \& Broughton, 1990).

\section{Chrono-Health}

A healthy human being oscillates regularly thoroughout life. This sentence may summarize the relevant contribution of chronobiology to contemporary medicine (Moore-Ede et al., 1982).

Neurology, psychiatry, and endocrinology (Kleitman, 1949; Richter, 1965; Boyar et al., 1972 ${ }^{\mathrm{a} . \mathrm{b}}$ ) were the branches of medical practice most immediately receptive to the emerging concepts. Pediatrics (Aserinsky \& Kleitman, 1955; Parmelee, 1961), cardiology (Halberg, 1986) and oncology (Hrushesky, 1985) came next, followed by gerontology (Richardson, 1990) and immunology (Plytycz \& Seljelid, 1997). 
In spite of the growing evidence, formal teaching of chronobiology at medical schools is in its infancy (Cambrosio \& Keating, 1983), sometimes as a singular course, sometimes spread over other courses such as Physiology, Neurosciences, and Sleep\&Consciousness.

\section{Breaking clocks}

Jet-lag and shiftwork are expressions readily linked to applications of chronobiology in these days of fast time-zone changes and flexible working hours. The adverse effects of submitting our timing system to abrupt phase shifts of zeitgeber are today universally recognized (Manfredini et al, 1998; Boggild \& Knutsson, 1999). The relevant questions have become: 1) how to minimize these effects (Eastman \& Martin, 1999), and 2) the origin of important interindividual differences in tolerance to such shifts (Folkard \& Monk, 1981; Menna-Barreto et al., 1993). Hospital routines are one of the important issues, not only from the clinical point of view but also from a legal perspective (Gaspar et al., 1998; Grossman, 1997).

\section{Currently Published Periodicals on Chronobiology}

Biological Rhythm Research. 4 issues /year. Official organ of the European Society for Chronobiology. Editor: W. J. Rietveld (Department of Physiology, University of Leiden, P.O. Box 9604, 2300 RC Leiden, Holanda). Published by Swets \& Zeitlinger Publishers, P.O. Box 825, 2160 SZ Lisse, Netherlands.

Chronobiology International. 6 issues/year. A Journal of Basic and Applied Biological Rhythm Research, bimestral. Official organ of the International Society for Chronobiology. Editors: Michael H. Smolensky (University of Texas, Houston, Health Science Center, P.O. Box 20186, Houston, TX, EUA. Fax: (713) 745-1956) e Ludger Rensing (Cell Biology FB2, University of Bremen, P.O. Box 330440, D-28334 Bremen, Alemanha. Fax: (49-421) 218-4042). Published by Lippincott-Raven Publishers, 227 East Washington Square, Philadelphia, PA 19106-3780, EUA.

Journal of Biological Rhythms. 4 issues/year. Official organ fo the Society for Research on Biological Rhythms. Editor: Fred W. Turek (Department of Neurobiology and Physiology, Northwestern University, 2153 North Campus Drive, Evanston, IL 60208-3520, EUA. F́ax: (708) 467-4065). Published by SAGE Science Press, 2455 Teller Road, Thousand Oaks, CA 91320, EUA.

Rythmes, Bulletin du Groupe d'Étude des Rythmes Biologiques. 4 issues / year. Bulletin of the Société Francophone de Chronobiologie. Editor: Bernard Canguilhem (Institut de Physiologie, Faculté de Médecine, 4 rue Kirschleger F67085 Strasbourg, CEDEX, França). Published by the Société Francophone de Chronobiologie, at the Université de Strasbourg. 


\section{Diffusion (general public)}

Cerejido M. La vida y el tiempo. In: Cerejido FB, ed. Del tiempo, Cronos, Freud, Einstein y los genes. Mexico, Folios Ediciones, México, 1983.

Leconte P, Lambert C. La Chronopsychologie, Collection "Que Sais-Je?” n n $^{\text {o }} 2549$. Paris: Presses Universitaires de France, 1990.

Moore-Ede M. The Twenty-Four-Hour Society. Reading: Addisson-Wesley Publishing Company, 1993.

National Commission on Sleep Disorders Research. Wake-up America: a national sleep alert. Secretary of the U.S. Department of Health and Human Services (HHS), USA, Program 470-M, 1993.

Perry S, Dawson J. 1988. The Secrets Our Body Clocks Reveal. MacMillan, 1988.

Racle G. La Science des Rythmes et la Vie Quotidienne. Paris: Editions RETZ, 1986.

Reinberg A. Des Rythmes Biologiques à la Chronobiologie. Paris: Gauthier-Villars, 1977.

Rose KJ. The Body in Time. New York: J Wiley \& Sons, 1988.

Siffre M. Beyond Time. New York, McGraw-Hill, 1964.

Thorneycroft T. Seasonal Patterns in Business and Everyday Life. Gower, 1987. Waterhouse JM, Minors DS, Waterhouse ME. Your Body Clock: How To Live With It Not Against It. Oxford: Oxford University Press, 1990.

\section{Methodology}

Borbély AA. A two process model of sleep regulation. Hum Neurobiol 1982;1:195204.

Cornélissen G, Halberg F, Stebbings J, Halberg E, Carandente F, Bartholomew H. Chronobiometry with pocket calculators and computer systems. La Ricerca Clin Lab $1980 ; 10(2): 333-85$.

Diggle PJ, Liang KY, Zeger SL. The Analysis of Longitudinal Data. Oxford: Oxford University Press, 1994.

Enright JT. The Timing of Sleep and Wakefulness, Studies in Brain Function, 3. Berlin: Springer-Verlag, 1980.

Girling AJ. Periodogram and spectral estimates. Biol Rhythm Res 1995;26(2):14972 .

Halberg F, Johnson EA, Nelson W, Runge W, Sothern R. Autorhythmometry procedures for physiologic self-measurements and their analysis. Physiol Teach 1972;1:1-11.

Kronauer RE. Modelling principles for human circadian rhythms. In: Moore-Ede MV,Czeisler CA, eds. Mathematical Models of the Circadian Sleep-Wake Cycle. New York: Raven Press, 1984. 
Kronauer RE, Czeisler CA, Pilato SF, Moore-Ede MC , Weitzman, ED. Mathematical model of the human circadian system with two interacting oscillators. Am J Physiol 1982;242:R13-R17.

Kronauer RE, Czeisler CA, Pilato SF, Moore-Ede MC, Weitzman ED. Mathematical representation of the human circadian system: two interacting oscillators with affect sleep. In: Chase MH, Weitzman ED, eds. Sleep disorders: basic and clinical research, New York: Spectrum, 1983.

Moore-Ede MC, Czeisler CA, editors. Mathematical Models of the Circadian Sleep-Wake Cycle. New York: Raven Press, 1984.

Pavlidis T. Mathematical models. In: Aschoff J, ed. Handbook of Behavioral Neurobiology vol 4 Biological Rhythms. New York: Plenum Press, 1981;41-54.

Shumway RH. Applied Statistical Time Series Analysis. Englewood Cliffs, NJ: Prentice Hall, 1988.

Strogatz SH. The Mathematical Structure of the Human Sleep-Wake Cycle. Berlin: Springer-Verlag, 1986.

Wever RA. Toward a mathematical model of circadian rhythmicity. In: Moore-Ede MC, Czeisler CA, eds. Mathematical Models of the Circadian Sleep-Wake Cycle. New York: Raven Press, 1984.

Winfree AT. The Timing of Biological Clocks. In: WH Freeman, ed. New York: Scientific American Library, 1987.

\section{Fundamentals of Chronobiology}

Ahlgren A, Halberg F. Cycles of Nature. An Introduction to Biological Rhythms. Washington, DC: National Science Teachers Association, 1990.

Aschoff J. From temperature regulation to rhythm research. Chronobiol Int 1990;7:179-86.

Aschoff J, Daan S, Groos GA, eds. Vertebrate circadian systems, structure and physiology. Berlin/Heidelberger: Springer-Verlag, 1982.

Aschoff J, Gerkema M. On diversity and uniformity of ultradian rhythms. In: Schulz $\mathrm{H}$, Lavie P, eds. Ultradian rhythms in physiology and behavior. Berlin: SpringerVerlag, 1985;321-34.

Brady J. Circadian rhythms - endogenous or exogenous. J Comp Physiol 1987;161A:711-14.

Brock MA. Chronobiology and aging. JAGS 1991;39:74-91.

Brown FM, Graeber RC. Rhythmic aspects of behavior. New York: Lawrence Erbaum, 1982.

Brown Jr FA. Response to pervasive geophysical factors and the biological clock problem. Cold Spring Harbor Symp Quant Biol 1960;25:57-71.

Brown Jr FA. A unified theory for biological rhythms: rhythmic duplicity and the genesis of 'circa' periodism. In: Aschoff J, ed. Circadian Clocks. Amsterdam: North Holland, 1965;231-61.

Brown Jr FA, Hastings JW, Palmer JD. The Biological Clock: Two Views. New York: Academic Press, 1970:1-94.

Cipolla-Neto J, Marques N, Menna-Barreto LS, editors. Introdução ao Estudo da 
Cronobiologia. São Paulo: Ícone Editora/Edusp, 1988.

Edmunds Jr LN. Cellular and Molecular Bases of Biological Clocks. Models and Mechanisms for Circadian Timekeeping. New York: Springer-Verlag, 1988.

Ehret CF, Wille JJ , Trucco E. The circadian oscillation: an integral and indissociable property of eukaryotic gene action systems. In: Chance, B, Pye, EK, Ghosh, AK, Hess, B, eds. Biological and Biochemical Oscillators. New York: Academic Press, 1973;503-12.

Gwinner, E. Circannual rhythms: endogenous annual clocks in the organization of seasonal reproduction. Berlin: Springer Verlag, 1986.

Halberg F. Temporal coordination of physiologic function. Cold Spring Harbor Symp Quant Biol 1960;25:289-310.

Halberg F. Claude Bernard, referring to an 'extreme variability of the internal milieu'. In: Claude Bernard and Experimental Medicine. Cambridge: Schenkman, 1967;193210.

Halberg F. Chronobiology. Annu Rev Physiol 1969;31:675-725.

Halberg F. History of Chronobiology [Abstract]. Chronobiologia 1979;6:183.

Halberg F. Chronobiology: methodological problems. Acta Med Rom 1980;18:399440.

Kleitman N. Sleep and wakefulness. Chicago: Univ Chicago Press, 1963.

Halberg F. Physiologic 24-hour periodicity: general and procedural considerations with reference to the adrenal cycle. $Z$. Vitamin-Hormon-Fermentforsch 1959;10:225296.

Hall JC, Rosbash M. Mutations and molecules influencing biological rhythms. Annu Rev Neurosci 1988;11:373-93.

Hall JC, Rosbash, M. Genetic analysis of biological rhythms. J Biol Rhythms 1987;2:153-78.

Hall, JC. Genetics of circadian rhythms. Annu. Rev Genet 1990;24:659-97.

Hastings JW, Rusak B , Boulos Z. Circadian rhythms: the physiology of biological timing. In: Prosser CL, ed. Neural and integrative animal physiology. New York: Wiley-Liss, Inc., 1991:435-546.

Hastings JW, Bode VC. Biochemistry of rhythmic systems. Ann N Y Acad Sci 1962;98:876-89.

Jung EG, Holick MF. Biologic effects of light. Proceedings of Symposium; 1993/ june, 3-5. Basel, Switzerland. Berlin/New York:Waiter de Gruyter, 1994.

Lloyd D, Rossi EL. Ultradian Rhythmicity in Biological Systems. An Inquiry into Fundamental Principles. London: Springer-Verlag, 1992.

Marques N , Menna-Barreto L, eds. Cronobiologia: Princípios e Aplicações. São Paulo: Edusp/Fiocruz, 1997.

Marques N, Menna-Barreto L, Golombek, D, eds. Cronobiología: Princípios y Aplicaciones. Buenos Aires: Eudeba,1997.

Palmer JD, Brown FA Jr, Edmunds LN Jr. An introduction to biological rhythms. New York/London: Academic Press, 1976.

Pittendrigh CS. Circadian rhythms and the circadian organization of living systems. Cold Spring Harbor Symp Quant Biol 1960;25:159-84.

Pittendrigh CS. Circadian systems: general perspective. In: Aschoff J, ed. Biological rhythms. Handbook of behavioral neurobiology. vol.4. New York: Plenum Press, $1981 ; 57-80$. 
Pittendrigh CS. Entrainment. In: Aschoff J, ed. Biological rhythms. Handbook of behavioral neurobiology. vol.4. New York: Plenum Press, 1981;95-124.

Pittendrigh CS. Temporal organization: reflections of a Darwinian clock-watcher. Annu Rev Physiol 1993;55:17-54.

Pittendrigh CS, Minis DH. Circadian systems: longevity as a function of circadian resonance in Drosophila melanogaster. Proc Nat Acad Sci USA 1972;69:1537-9.

Rusak B. Vertebrate behavioral rhythms. In: Aschoff J, ed. Handbook of Behavioral Neurobiology, Biological Rhythms, vol.4. New York: Plenum Press, 1981;183-213.

Schulz, H, Lavie P., eds. Ultradian Rhythms in Physiology and Behavior. Experimental Brain Res. Springer-Verlag, Berlin/Heidelberger, 1985; 12(suppl).

Van Cauter E, Honickx E. The pulsatility of pituitary hormones. In: Schulz H, Lavie P, eds. Ultradian rhythms in physiology and behavior. Berlin: Springer-Verlag, 1985;4160.

Waterhouse JM , Minors DS. Masking and entrainment. In: Hekkens WTJ, Kerkhof GA, Rietveld WJ, eds. Trends in Chronobiology. Oxford: Pergamon Press. 1988; 163-71.

Zatz, M, ed. Circadian Rhythms. Discussions in Neuroscience 1992;8(2-3):1-124.

\section{Human Chronobiology}

Andrade MMM, Benedito-Silva AA , Menna-Barreto, L. Correlations between morningnesseveningness character, sleep habits and temperature rhythm. Brazilian J Med Biol Res 1992;25:835-9.

Aschoff $\mathrm{J}$, Wever $\mathrm{R}$ The circadian system of man. In: Aschoff $\mathrm{J}$, ed. Handbook of behavioral neurobiology, vol. 4: Biological Rhythms. New York: Plenum Press, 1981. Aschoff J. Circadian rhythms in man. Science 1965;148:1427-32.

Aschoff J. Masking of circadian rhythms by zeitgebers as opposed to entrainment. In: Hekkens WTJM, Kerkhof GA, Rietveld WJ, eds. Trends in chronobiology. Oxford: Pergamon Press, 1988:149-61.

Aschoff J. On mood and activity in humans in temporal isolation. In: Hiroshige T, Honma K, eds. Circadian clocks from cell to human. Hokkaido: University Press Sapporo, 1992:53-70.

Aschoff J, Gerecke U, Wever R. Desynchronizaiton of human circadian rhythms. J Physiol $1967 ; 17: 450$.

Benoit O. Le rythme veille-sommeil chez l'enfant: I. Physiologie. Arch Fr Pediatrl 1981;38:619-26.

Binkley S, Tome MB, Crawford D, Mosher K. Human daily rhythms measured for one year. Physiol Behav 1990;48:293-8.

Binkley S, Tome MB, Mosher K. Weekly phase shifts of rhythms self-reported by almost feral human students in the USA and Spain. Physiol Behav 1989;46:423-7.

Binkley S. Wrist activity in a woman: Daily, weekly, menstrual, lunar, annual cycles. Physiol Behav 1992:411-21.

Blehar MC, Lewy AJ. Seasonal mood disorders: consensus and controversy. Phychopharmacol Bull 1990;26:465-94.

Borbély AA , Tobler I. The search for an endogenous "sleep-substance". Trends in Pharmacol 1980;1:356-8.

Boyar, RM, Rosenfeld, RS, Kapen, S, Finkelstein, JW Roffwarg, HP, Weitzman, ED, 
Hellman, L. Human puberty: simultaneous augmented secretion of LH and testosterone during sleep. $\mathrm{J}$ Clin Invest 1974;54:609-18.

Brandenberger G, Charloux A, Gronfier C , Otzenberger H. Ultradian rhythms in hydromineral hormones. Horm Res 1998; 49(3-4):131-5.

Campbell, J. Winston Churchill's Afternoon Nap. New York: Simon and Schuster, 1986.

Coeverden, AV, Mockel, J, Laurent, E, Kerkhofs, M, L'Hermite-Baleriaux, M, Decoster, C, Neve, P, Van Cauter, E. Neurendocrine rhythms and sleep in aging men. Am J Physiol 1991;260:651-61.

Crepon, P. Les Rythmes de vie de l'enfant du tout petit a l'adolescent. Paris: Editions Retz, 1990.

Crouter AC, Mguire MC. Seasonal and weekly rhythms: windows into variability in family socialization experiences in early adolescence. New Dir Child Dev 1998;(82):69-82.

Crowley Jr WF, Hofler C. The Episodic Secretion of Hormones. New York: Wiley, 1987.

Czeisler C, Weitzman ED, Moore-Ede MC, Zimmerman JC , Knauer RS. Human sleep: its duration and organization depend on its circadian phase. Science 1980;210:1264-7.

Daan S, Beersma DGM. Circadian gating of human sleep-wake cycles. In: Moore-Ede MC, Czeisler CA, eds. Mathematical models of the circadian sleep-wake cycle. New York: Raven Press, 1984.

Daan S, Beersma DGM, Borbély AA. Timing of human sleep: recovery process gated by a circadian pacemaker. Am J Physiol 1984;246:R161-R178.

D'Agatha R, Vigneri R , Polosa P. Chronobiological study on growth hormone secretion in man: its relation to sleep-wake cycles and to increasing age. In: Scheving LE, Halberg F, Pauling JE, eds. Chronobiology. Tokyo: Iguku Shoin, 1974.

DeVecchi A, Carandente F, Fryd DS, Halberg F, Sutherland DE, Howard RJ, Simmons RL , Najarian JS. Circaseptan (about 7-day) rhythm in human kidney allograft rejection in different geographic locations. In: Reinberg A, Halberg F, eds. Chronopharmacology. Proceedings of the $7^{\text {th }}$ Satellite Symposium of the International Congress of Pharmacology. Oxford: Pergamon Press, 1979:193-202.

Dinges DF, Broughton RJ. Sleep and Alertness. Chronobiological, behavioral, and medical aspects of napping. New York: Raven Press, 1989.

D'Souza SW, Tenreiro S, Minors D, Chiswick ML, Sims DG, Waterhouse J. Skin temperature and heart rate rhythms in infants of extreme prematurity. Arch Dis Child 1992;84-8.

Ferin M, Halberg F, Richart RM, Wiele RLV, eds. Biorhythms and human reproduction. New York: John Wiley:\& Sons, 1974.

Folkard S. The pragmatic approach to masking. Chronobiol Int 1989;6:55-64.

Gambacciani M, Liu JH, Swartz WH, Tueros VS, Rasmussen DD, Yen SSC. Intrinsic pulsatility of ACTH release form the human pituitay 'in vitro'. Clin Endocrinol Oxford 1987;26:557-63.

Gambacciani M, Liu JH, Swartz WH, Tueros VS, Yen SSC, Rasmussen DD. Intrinsic pulsatility of luteinizing hormone release from the human pituitary 'in vitro'. Neuroendocrinology 1987;45;402-6.

Gander PH, MacDonald JA, Montgomery JC, Paulin MG. Adaptation of sleep and 
circadian rhythms to the Antarctic summer: a question of zeitgeber strength. Aviation \& Space Environment Medicine 1991;62:1019-25.

Griffith S, Folkard S, Bojkowski C, English J, Arendt J. Persistent $24 \mathrm{~h}$ variations of 6hydroxy melatonin sulphate and cortisol in Antarctica. Experientia 1986;42:430-2.

Halberg F, Simpson H. Circadian acrophase of human 17-hydroxycorticosteroid excretion referred to midsleep rather than midnight. Human Biology 1967;39:40513.

Halberg F. Biologic rhythms, hormones and aging. In: Vernadakis A, Timiras PS, eds. Hormones in development and aging. New York: Spectrum Publications, 1981:45176.

Halberg F, Marques N, Cornélissen G, Bingham C, Sánchez de la Peña S, Halberg J, Marques M, Jinyi W, Halberg E. Circaseptan biologic time structure reviewed in the light of contributions by Laurence K. Cutkomp and Ladislav Derer. Acta Entomologica Bohemoslovaca 1990;87:1-29.

Hastings MH, Duffield GE, Smith EJ, Maywood ES, Ebling FJ. Entrainment of the circadian system of mammals by nonphotic cues. Chronobiol Int 1998;15(5):425-45.

Hines TM. Comprehensive review of biorhythm theory. Psychol Rep 1998;83(1):19-64.

Horne JA. Why We Sleep: The functions of sleep in human and other mammals. Oxford/New York: Oxford University Press, 1988.

Inoue M, Koyanagi T, Hakahara H, Hara K, Hori E, Nakano H. Functional development of human eye movement in utero assessed quantitatively with real-time ultrasound. Am J Obstet Gynecol 1986;155:170-4.

Jacques SL, Weaver DR, Reppert SM. Penetration of light into the uterus of pregnant mammals. Photochem Photobiol 1987;45:637-41.

Jores A. Physiologie und Pathologie der 24-Stunden-Rhythmik des Menschen. Erg. d. inn. Med 1935;48:1-574.

Kagen S, Boyar RM, Finkelstein JW, Hellman L, Weitzman ED. Effect of sleep-wake cycle reversal on luteinizing hormone secretory pattern in puberty. $J$ Clin Endocrinol Metab 1974;39:293-9.

Kapen S, Boyar R, Hellman L, Weitzman E. Twenty-four-hour patterns of luteinizing hormone secretion in humans: ontogenetic and sexual considerations. Prog Brain Res 1975;42:103-13.

Karsch FJ, Bittman EL, Foster DL, Goodman RL, Legan SJ, Robinson JE. Neuroendocrine basis of seasonal reproduction. Recent Prog Horm Res 1984;40:185-222.

Kerkhof GA. Inter-individual differences in the human circadian system: a review. Biol Psychol 1985;20:83-122.

Kleitman N, Engelmann TG. Sleep characteristics of Infants. J App Physiol 1953;6:26982.

Lavie P. The search for cycles in mental performance from Lombard to Kleitman. Chronobiologia, 1980;7:247-256.

Lavie P. Ultradian rhythms in arousal - the problem of masking. Chronobiol Int 1989;6:218.

Lercherl A, Simoni M, Nieschlag E Changes in seasonality of birth rates in Germany 
from 1951 to 1990. Naturwissenschaften 1993;80:516-8.

Lobban MC , Tredre BE. Diurnal rhythms of renal excretion and of body temperature in aged subjects. J Physiol 1967;188:48-49.

Lodemore MR, Petersen SA, Wailoo MP. Factors affecting the development of night time temperature rhythms. Arch Dis Child 1992;67:1259-61

Lohr B, Siegmund R. Ultradian and circadian rhythms of sleep-wake and food-intake behavior during early infancy. Chronobiol Int 1999;16(2):129-48.

Lombard WP. The variations of the normal knee-jerk and their relation to the activity of the central nervous system. Am J Psychol 1887;1:5-71.

Marotte H, Timbal J. Circadian rhythm of temperature in man. Comparative study with two experimental protocols. Chronobiologia1981;8:87-100.

Menna-Barreto L, Montagner H, Soussignan R, Koch P. The sleep/wake cycle in 4- to 14- month old children: general aspects and sex differences. Brazilian J Med Biol Res 1989;22:103-6.

Moore RY. Circadian rhythms: basic neurobiology and clinical apllications. Annu Rev Med 1997;48:253-66.

Mosso U. Recherches sur l'ínversion des oscillations diurnes de la température chez l'homme normal. Arch Ital Biol 1887;8:177-85.

Price DA, Close GC, Fielding BA. Age of appearance of circadian rhythm in salivary cortisol values in infancy. Arch Dis Child 1983;58:454-6.

Quéinnec Y, Devolvé N. Behavioural Rhyhtms. Readings from the 19th International Ethological Conference. Toulouse: Privat IEC/Université Paul Sabatier, 1986.

Reame N, Sauder SE, Kelch RP, Marshall JC. Pulsatile gonadotropin secretion during the human menstrual cycle: Evidence for altered frequency of gonadotropin releasing hormone secretion. J Clin Endocrinol \& Metab 1984; 59:328-37

Rebar RW, Yen SS. Endocrine rhytms in gonadotropins and ovarian steroids with reference to reproductive processes. In: Krieger DT, editor. Endocrine Rhythms. New York: Raven Press, 1979:259-98.

Redlin U, Mrosovsky N . Exercise and human circadian rhythms: what we know and what we need to know. Chronobiol Int 1997;14(2):221-9.

Regal PJ, Connolly MS. Social influences on biological rhythms. Behaviour 1980;72: 171-99.

Reilly T, Atkinson G, Waterhouse J. Biological Rhythms and Exercise. Oxford: Oxford University Press, 1996.

Richter CP. Sleep and activity: their relation to the 24-hour clock. Proc Assoc Res Nerv Mental Diseases, 1967;45: 8-27.

Roenneberg T, Aschoff J.'Annual rhythm of human reproduction: I. Biology, sociology or both? J Biol Rhythms 1990;5:195-216.

Rosenthal, NE. Seasons of the Mind. New York: Guilford Publications, 1989:278.

Thoman EB, Acebo C, Lamm S. Stability and instability of sleep in older persons recorded in the home. Sleep 1993;16:578-85.

Wailoo MP, Petersen SA, Whittaker H, Goodenough P. Sleeping body temperature in 3-4 month old infants. Arch Dis Child 1989;64:596-9.

Wakayama K, Ogawa T, Goto K , Sonoda H. Development of ultradian rhythm of EEG acitvities in premature babies. Early Hum Dev 1993;32:11-30. 
Wehr TA. Effect of seasonal changes in daylength on human neuroendocrine function. Horm Res 1998;49(3-4):118-24.

Wever RA. Internal interactions within the human circadian system: the masking effect. Experientia 1985;41:332-42.

Wever RA. Properties of human sleep-wake cycles: parameters of internally sincronized free-running rhythms. Sleep 1984;7:25-51.

Wittmann M. Time perception and temporal processing levels of the brain. Chronobiol Int $1999 ; 16(1): 17-32$.

\section{Medicine}

Allan TM, Douglas AS. Seasonal Variation in Health and Diseases (with sections on effects of weather and temperature). A Bibliography. Dorset: Mansell, Cassel PLC, 1994.

Arendt J, Waterhouse JM, Minors DS, eds. Biological rhythms in clinical practice. London: Butterworths \& Co. Publishers Ltd., 1989.

Armstrong SM , Chesworth MJ . The pineal gland. In: Trentini GP, De Gaetari C, Pevet P, eds. Fundamentals and Clinics in Pineal Research. New York: Raven Press. 1987.

Carandente F. Elementi di Cronobiologia Sperimentale e Clinica. Milano: Casa Editrice Il Ponte, 1990.

Carandente F, Dammacco F , Halberg F, editors. Chronoimmunomodulation by an Antimicrobial Agent, 1989, (special issue). Chronobiologia 1988;15(1/2):3-189. Coleman, RM, ed. Wide Awake at 3 a.m. by choice or by chance. W.H. Freeman \& Co. Ltd., 1986.

Cornelissen G, Bakken E, Delmore P, Orth-Gomér K, Akerstedt T, Caradente F , Halberg, F 1990. From various kinds of heart rate variability to chronocardiology. Am J Cardiol 1990;66:863-8.

Cornélissen G, Halberg E. Chronobiology Pertinent to Gynecologic Oncology. Medtronic Chronobiology Seminar Series $n^{\circ} .5$, Minneapolis: University of Minnesota, 1992.

Costa A, Leston JA, Cavallini A, Nappi G. Cluster headache and periodic affective illness: common chronobiological features. Funct Neurol 1998;13(3):263-72

Diez-Noguera A, Cambras T, editors. Chronobiology \& Chronomedicine. Basic Research and Applications. Proceedings of the $6^{\text {th }}$ Annual Meeting of the European Society for Chronobiology, 1990 July. Barcelona: Verlag Peter Lang, Frankfurt/ Berlin/New York/Paris, 1992.

Dijk DJ, Duffy J F. Circadian regulation of human sleep and age-related changes in its timing, consolidation and EEG characteristics. Ann Med 1990;31(2):130-40.

Dreifuss FE, Meinardi H, Stefan H. Chronopharmacology in Therapy of the Epilepsies. Raven Press, New York, 1990.

Empson JA, Purdie DW. Effects of sex steroids on sleep. Ann Med 1999;31(2):141-5.

Haen E, Halberg F. Chronopharmakologie und Chronotherapie. DT Aerztebl. 1985;B82:3837-48.

Halaris A, ed. Chronobiology and Psychiatric Disorders. New York: Elsevier Science Publishers, 1987. 
Halberg F. Chronobiology of Human Blood Pressure, A Medtronic Seminar, 4th edition. Minneapolis: Medtronic, 1988:1-242

Halberg F, Howard RB. 24-hour periodicity and experimental medicine. Example and interpretations. Postgrad Med 1958;24:349-58.

Halberg F, Watanabe H, eds. 1992. Chronobiology and Chronomedicine. Workshop on Computer Methods on Chronobiology and Chronomedicine, $20^{\text {th }}$ International Conference of Neurovegetative Research: 1990 Sep 10-14. Tokio: Medical Review, 1992.

Halberg F, Reale L, Tarquini B, eds. Chronobiologic Approach to Social Medicine. Proceedings of the II International Symposium, 1984 Oct 2: Instituto Italiano Medicina Sociale, Roma, 1986: 791.

Halberg F. Some physiological and clinical aspects of 24-hour periodicity. Lancet 1953;73:10-31.

Halberg F, Haus E, Scheving LE. Sampling of biologic rhythms, chronocytokinetics and experimental oncology. In: Valleron JJ, McDonald PDM, eds. Biomathematics and Cell Kinetics. Amsterdan: Elsevier North-Holland, 1978:175-90.

Haus E, Lakatua DJ, Sackett-Lundeen LL. Chronobiology in laboratory medicine. In: Rietveld WJ, ed. Clinical Aspects of Chronobiology. 1987:13-84.

Hrushesky WJM. The multifrequency (circadian, fertility cycle, and season) balance between host and cancer. In: Hrushesky WJM, Langen R, Theeuwes F, eds. Temporal Control of Drug Delivery. New York: Ann N Y Acad Sci 1991;618:218256.

Hrushesky WJM. Automatic chronotherapy: an integral part of the future of medicine. In: Hekkens WTJM, Kerkhof GA, Rietveld WJ, eds. Trends in Chronobiology. Oxford: Pergamon Press, Advances in the Biosciences 73, 1988:281-93.

Hrushesky WJM. Cancer chronotherapy: a drug delivery challenge. In: Hayes DK, Pauly JE, Reiter RJ, eds. Chronobiology: its role in clinical medicine, General Biology, and Agriculture. Part A. New York: Wiley-Liss Inc., 1990:1-10.

Hrushesky WJM, Langer R, Theevwes F. eds. Temporal control of drug delivery. Annals of The New York Academy of Sciences $n^{\circ}$ 618. New York: New York Academy of Sciences, 1991.

Hrushesky W, Sanchez S, Levi F, Brown H, Halberg F, Haus E, Sothern R, Kennedy BJ. Total RNA content of cancer patients' mononuclear cells demonstrate marked circadian rhythmicity. Blood 1981;54(suppl 1):221-79.

Hrushesky WJM, ed. Circadian Cancer Therapy. CRC Press, Inc., Boca Raton, FL, 1994.

Kupfer DJ, Monk TH, Barchas JD. Biological Rhythms and Mental Disorders. New York/London: The Guilford Press, 1988.

Lemmer B. Chronopharmacology: Cellular and Biochemical Interactions. Cellular Clock Series, v. 3. Marcel Dekker, Inc., 1989.

Martins RWT, Araujo JF, Marques N. A Cronobiologia na prática médica e na Reumatologia. Rev Bras Reumatol 1994;34:81-92.

Montplaisir J, Godbout R. Sleep and Biological Rhythms. Basic Mechanisms and Applications to Psychiatry. Oxford: Oxford University Press, 1990. 
Morley JE, Roth T. editors. Sleep Disorders and Insomnia in the Elderly. Facts and Research in Gerontology, vol. 2. New York: Springer Publishers, 1993.

Muller JE Circadian variation in cardiovascular events. Am J Hypertens 1999;12(2 Pt 2):35S-42S.

Otsuka K, Cornélissen G, Halberg F, eds. Chronocardiology and Chronomedicine: Humans in Time and Cosmos. Tokio: Life Science Publishing, 1993.

Reinberg AE, Labrecque G, Smolensky, MH. Chronobiologie et Chronotherapeutique, Heure Optimale d'Administration des Medicaments. Paris: Medicine-SciencesFlammarion, 1991.

Rietveld WJ, editor. Clinical Aspects of Chronobiology. CIP-Gegevens Koninklijke Bibliot. Holand: Den Haag.

Rivkees SA. Developing circadian rhythmicity. Basic and clinical aspects. Pediatr Clin North Am 1997;(44)2:467-87.

Rosenthal NE, Sack DA, Gillin JC, Lewy AJ, Goodwin FK, Davenport, Y, Mueller PS, Newsome DA, Wehr TA. Seasonal affective disorder: A desciption of the syndrome and preliminary findings with light therapy. Arch Gen Psychiatry 1984;41:72-80.

Scheen AJ, Van Cauter E.The roles of time of day and sleep quality in modulating glucose regulation: clinical implications. Horm Res 1998;49(3-4):191-201

Sedgwick PM. Disorders of the sleep-wake cycle in adults. Postgrad Med J 1998;74(869):134-8.

Shephard RJ, Shek PN. Interactions between sleep, other body rhythms, immune responses, and exercise. Can J App Physiol 1997; 22(2):95-116.

Siever LJ, Coccaro EF , Davis KL. Chronobiologic instability of the noradrenegic system in depression. In: A Halaris, ed. Chronobiology and Psychiatric Disorders. New York: Elsevier Sciencie Publishing, 1987;1-21.

Smolensky MH , D’ Alonzo GE. Biologic rhythms and medicine. Am J Med 1988;85(suppl 1B): 34-46.

Smolensky MH , Reinberg A. Clinical chronobiology: relevance and applications to the practice of occupational medicine. In: Scott AJ, ed. Shiftwork. Occupational medicine: State of Art Reviews, 1990;5:239-72.

Smolensky MH, D’Alonzo, GE, Kunkel G, Barnes PJ, editors. Circadian Rhythm-Adapted Theophylline Schedules for Asthma. Chronobiol Int 1987;(Special Issue)4(3):301466.

Touitou Y, Haus E, editors. Biologic Rhythms in Clinical and Laboratory Medicine. Berlin: Springer-Véralg, 1992:730.

Van Cauter E, Plat L, Leproult R, Copinschi G. Alterations of circadian rhythmicity and sleep in aging: endocrine consequences. Horm Res 1998;49(3-4):147-52.

Van Cauter E, Polonsky KS , Scheen AJ. Roles of circadian rhythmicity and sleep in human glucose regulation. Endocrinol Rev 1997;18(5):716-38.

Waterhouse J, Minors D, Atkinson G, Benton D. Chronobiology and meal time: internal and external factors. Br J Nutr 1997;77(Suppl 1):S29-38. 
Wehr TA. Chronobiology of affective illness. In: Hekkens WThJM, Kerkhof GA, Rietveld WJ, eds. Trends in Chronobiology. Oxford: Pergamon Press. Adv Biosciences 1988;73:367-79.

Zerssen D von. Circadian phenomenon in depression: theoretical concepts and empirical findings. In: Hekkens WThJM, Kerkhof GA, Rietveld WJ, eds. Trends in Chronobiology. Oxford: Pergamon Press, Adv Biosciences 1988;73:357-66.

Zucker I. Seasonal affective disorders: Animal models non fingo. $J$ Biol Rhythms 1988;3:209-23.

\section{Pineal, melatonin and light}

Arendt J. Melatonin. Clin Endocrinol 1988;29:205-29.

Arendt J. Melatonin and the Mammalian Pineal Gland. London: Chapman \& Hall, 1995.

Arendt J. Complex effects of melatonin. Therapie 1998;53(5):479-88.

Arendt J. Melatonin and the Mammalian Pineal Gland. London/Glasgow/Weinhein: Chapman \& Hall, 1995:350.

Cardinali DP. Melatonin. A mammalian pineal hormone. Endocrinol Rev 1981;2:32746.

Cardinali DP, Golombek DA, Rey RAB. Relojes y Calendários Biológicos. La Sincronia del Hombre con el Medio Ambiente. Mexico/Buenos Aires: Fondo de Cultura Económica, 1992.

Cassone VM. Melatonin's role in vertebrate circadian rhythms. Chronobiol Int 1998;15(5):457-73.

Fellenberg AM, Phillipou G, Seamark RF. Measurement of urinary production rates of melatonin as an index of human pineal function. Endocr Res Comm 1981;7:16775.

Honma K, Hashimoto S, Endo T , Honma S. Light and plasma melatonin rhythm in humans. Biol Signals 1997;6(4-6):307-12.

Lewy AJ, Wehr TA, Goodwin FK. Light suppresses melatonin secretion in humans. Science 1990;210:1267-9.

Lewy AL, Sack RL, Miller S , Hoban TM. Antidepressant and circadian phase shifting. Effects of light. Science 1987;235:352-4.

Morita $\mathrm{T}$, Tokura $\mathrm{H}$. The influence of different wavelenghts of light on human biological rhythms. App Hum Sc1 1998;17(3):91-6.

Reiter RJ. Pineal melatonin: cell biology of its synthesis and of its physiological interactions. Endocr Rev 1991;12:151-80.

Reiter RJ. Melatonin and human reproduction. Ann Med 1998;30(01):103-8.

Rosenthal NE, Blehar MC. Seasonal Affective Disorders and Phototherapy. New York/ London: The Guilford Press, 1989.

Skene DJ, Lockley SW , Arendt J. Melatonin in circadian sleep disorders in the blind. Biol Signals 1999;8(1-2):90-5.

Srinivasan V. Melatonin, biological rhythm disorders and phototherapy. Indian $\mathrm{J}$ Physiol Pharmacol 1997;41(4):309-28. 
Terman $M$ On the question of mechanism in phototherapy for seasonal affective disorder: Considerations of clinical efficacy and epidemiology. J Biol Rhythms 1988;3:155-72.

Wetterberg L, editor. Light and Biological Rhythms in Man. Wenner Gren International Series, vol. 63. Tarrytown, NewYork: Pergamon, 1994:448.

Wirz-Justice A. Beginning to see the light. Arch Gen Psychiatry 1998;55(10):861-2.

Wurtman RJ, Lieberman HS. Melatonin secretion as a mediator of circadian variations in sleep and sleepiness. J Pineal Res 1985;1:301-3.

\section{Neuroanatomy \& neurophysiology of the timing system}

Aguilar-Roblero R, Drucker-Colín R. The role of the suprachiasmatic nuclei in the regulation of circadian rhythms in mammals. Bol Estud Med Biol 1987;35:35-51.

Eastman C. Are Separate Temperature and Activity Oscillators Necessary to Explain the Phenomena of Human Circadian Rhythms? In: Moore-Ede MC, Czeisler CA, eds. Mathematical Models of the Circadian Sleep-Wake Cycle. New York: Raven Press, 1984.

Klein DC, Moore RY , Reppert SM. The Suprachiasmtic Nucleus: The Mind's Clock. New York: Oxford University Press, 1991.

Moore RY, Eichler VB. Loss of a circadian adrenal corticosterone rhythm following suprachiasmatic lesions in the rat. Brain Res 1972;42:201-6.

Moore RY, Lenn NJ. A retinohypothalamic projection in the rat. J Comp Neurol 1972;146:1-14.

Moore RY. Organization and function of a central nervous system circadian oscillator: The suprachiasmatic hypothalamic nucleus. Fed Proc 1983;42:2783-9.

Reppert SM , Schwartz WJ. Functional activity of the suprachiasmatic nuclei in the fetal primate. Neurosci Lett 1984;46:145-9.

Reppert SM, Schwartz WJ. Maternal coordination of the fetal biological clock in utero. Science 1983;220:969-71.

Reppert SM, Schwartz WJ. Maternal suprachiasmatic nuclei are necessary for maternal coordination of the developing of the circadian sleep. J Neurosci 1986;6:2724-9.

Reppert SM. Pre-natal development of a hypothlamic biological clock. Prog Brain Res 1992;93:1 19-32.

Rosenwasser AM, Adler NT. Structure and function in circadian timing system: Evidence for multiple coupled circadian oscillators. Neurosci Biobehav Rev 1986; 10: 431-48.

Rusak B , Zucker I. Neural regulation of circadian rhythms. Physiol Rev 1979;59:449526.

Stephan FK , Zucker I. Circadian rhythms in drinking behavior and locomotor activity of rats are eliminated by hypothalamic lesions. Proc Nat Acad Sci 1972;69:1583-6.

Turek FW, Van Reeth O. Altering the mammalian circadian clock with the shortacting benzodiazepine, triazolam. Trends in Neurosci 1988;11:535-41

Turek FW. Circadian neural rhythms in mammals. Annu Rev Physiol 1985;47:49-64. 


\section{Shiftwork}

Akerstedt T. Sleepiness as a consequence of shift work. Sleep 1988;11:17-34.

Akerstedt $\mathrm{T}$. Is there an optimal sleep-wake pattern in shift work? Scand $\mathrm{J}$ Work Environ Health 1998;24(suppl.)3:18-27.

Angersbach D, Knauth P, Loskant H, Karvonen MJ, Undeutsch K , Rutenfranz J. A retrospective cohort study comparing complaints and diseases in day and shift workers. Int Arch Occup Environ Health 1980;45:127-40.

Aschoff J. Features of circadian rhythm relevant for the design of shift schedules. Ergonomics 1978;21:739-54.

Bjerner B, Holm A, Swensson A. Diurnal variations in mental performance: a study of three-shift workers. Bri $\mathrm{J}$ Ind Med 1955;12:103-10.

Brown D. Shiftwork: a survey of the sociological implications of studies of male shiftworkers. J Occup Psychol 1975;48:231-40.

Brown FM, Fischer, FM , Lieber RR. Critique of 17 models of shiftwork effects. 1994. In: Abstracts of the $11^{\text {th }}$ International Symposium on Night and Shift Work.. Wallace M, Greenwood K, Smith P, eds. Melbourne: La Trobe University, Glenn College, 1994:9-11.

Carter FA, Corlett EN. Shiftwork and accidents. In: Psychological Approaches to Night and Shift Work.. Wedderburn A, Smith P, editors. Edinburgh: Heriott-Watt University, Seminar paper 3, 1982:3.1-3.11.

Comperatore CA , Krueger GP. Circadian rhythm desynchronosis, jet lag, shift lag, and coping strategies. In: Scott AJ, ed. Shiftwork. Occupational Medicine: State of Art Reviews. Philadelphia: Hanley \& Belfus Inc., 1990:323-41.

Corlett EN, Queinnec Y, Paoli P. Adapting shiftwork arrangements. European foundation for the improvement of living and working conditions. Dublin: Prinset \& Design, Ltd., 1988.

Costa G, Ghirlanda G, Minors DS , Waterhouse JM. Effect of bright light on tolerance to night work.. Scand J Work Environ Health 1993;19:414-20.

Costa G, Cesana GC, Kogi K, Wedderburn A, editors. Shiftwork: Health, Sleep and Performance - Studies in Industrial and Organizational Psychology vol.10, Proceedings of the $9^{\text {th }}$ International Symposium on Night and Shiftwork: 1989: Verona, Italy. Peter Lang, Frankfurt AM, 1990.

Craig A, Baer K, Diekmann A. The effects of lunch on sensory-perceptual functioning in man. Int Arch Environ Health 1981;49:105-14.

Czeisler CA, Johnson MP, Duffy JF, Brown EN, Ronda JM , Kronauer RE 1990. Exposure to bright light and darkness to treat physiologic maladaptation to night work. New Eng J Med 1990;322:1253-9.

Czeisler CA, Moore-Ede MC, Coleman RM. Rotating shift work schedules that disrupt sleep are improved by applying circadian principles. Science 1982;217:460-3.

Folkard S , Akerstedt T. Towards a model for the prediction of alertness and/ or fatigue on different sleep/wake schedules. In: Oginski A, Pokorski J, Rutenfranz J, eds. Contemporary Advances in Shiftwork Research. Krakow: Medical Academy, 1987:231-40.

Folkard S. Diurnal variation. In: Hockey GRJ, ed. Stress and Fatigue in Human Performance. John Wiley \& Sons, 1983:245-270. 
Froberg JE. Sleep deprivation and prolonged working hours. In: Hours of Work. Temporal Factors in Work- Scheduling. Chichester: John Wiley \& Sons, 1985:67-75.

Haider M, Cervinka R, Koller M, Kundi M. A destabilization theory of shiftwork effects. In: Hekkens WThJM, Kerkhof GA, Rietveld WJ, eds. Trends in Chronobiology. Oxford, Pergamon Press, 1988:209-17.

Harris W. Fatigue, circadian rhythm and truck accidents. In: Vigilance: Theory, Operational Performance, and Physiologyogical Correlates. Mackie F, editor. New York: Plenum Press, 1977:133-46.

Hildebrandt G, Stratmann I. Circadian system response to night work in relation to the individual circadian phase position. Int Arch Occup Environ Health 1979;43:7383.

Hildebrandt G, Rohmert W, Rutenfranz J. Twelve and 24 hour rhythms in error frequency on locomotive drivers and the influence of tiredness. Int $\mathrm{J}$ Cronobiol 1974;2:97-110.

Knauth P, Rutenfranz J. Experimental shiftwork studies of permanent night, and rapidly rotating, shift systems. Int Arch Occup Environ Health 1976;37:125-37.

Knauth P, Landau K, Droge C, Schwitteck M , Widynski, M. Duration of sleep depending on the type of shift work. Int Arch Occup Environ Health 1980;46:167-77.

Knutsson A. Shiftwork and coronary heart disease. Scand J Med 1989; 44(suppl):

Knutsson A, Akerstedt T, Jonsson BG, Orth-Gomér K. Increased risk of ischaemic heart disease in shift workers. Lancet 1986;2:89-92.

Kogi K, Thurman JE. Trends in approaches to night and shiftwork and new international standards. Ergonomics 1993;36:3-13.

Koller M. Health risks related to shift work. An example of time-contingent effects of long-term stress. Intl Arch Occup Environ Health 1983;53:59-75.

Kundi M, Koller M,Cervinka R , Haider M. Health and psychosocial aspects of shiftwork results of a 5 year follow-up study. In: Haider M, Koller M, Cervinka R, eds. Night and shiftwork: longterm effects and their prevention. Frankfurt: Peter Lang, 1986;81-92. (Studies in Industrial and Organizational Psychology, 3).

Monk TH. Shiftwork: determinants of coping ability and areas of application. In: Hekkens WThJM, Kerkhof GA, Rietveld WJ, eds. Trends in chronobiology. Oxford: Pergamon Press, 1988; 195-207.

Monk TH. Shiftworker performance. In: Scott AJ, ed. Shiftwork. Occupational Medicine: State of the Art Reviews, 5. Philadelphia: Hanley \& Belfus, 1990;183-98.

Monk, TH. How to Make Shiftwork Safe and Productive. Amer Soc Safety Engineers, Des Plaines, Il, 1988.

Monk, TM Sleep, Sleepiness and Performance. Chichester/New York/Brisbane: John Wiley \& Sons, 1991.

Mrosovsky N , Salmon PA. Triazolam and phase-shifting acceleration reevaluated. Cronobiol Int 1990;7:35-41,

Oginski A, Pokorski J, Rutenfranz J, editors. Contemporary Advances in Shiftwork Research: Theoretical and Practical Aspects in the Late Eighties. Proceedings of the $8^{\text {th }}$ International Symposium on Night and Shiftwork, Krakow e Konink, June 22-26, 1987. Krakow: Medical Academy, 1987.

Orth-Gomér K. Intervention on coronary risk factors by adapting a shiftwork schedule to biologic rhythmicity. Psychosom Med 1983;45:407-15. 
Pokorny MLI, Blom DHJ , Van Leeuwen P. Shifts, duration of work and accident risk of bus drivers. Ergonomics 1987;30:61-88.

Price W J , Holley DC. Shiftwork and safety in aviation. In: Shiftwork. Occupational Medicine: State of Art Reviews. 5, Philadelphia: Hanley \& Belfus, Inc. 1990:343-77.

Reinberg A, Andlauer P, Guillet P, Nicolai A, Vieux N, Laporte A. Oral temperature, circadian rhythm amplitude, ageing and tolerance to shiftwork. Ergonomics 1980;23:55-64.

Rutenfranz J, Knauth P, Fischer FM. Trabalho em Turnos e Noturno. São Paulo: Editora Hucitec, São Paulo, 1989.

Smith A , Miles C. Acute effects of meals, noise and shiftwork. Br J Psychol 1986; 77: 377-87.

Smolensky MH.The chronoepidemiology of occupational health and shift work. In: Reinberg A, Vieux N, Andlauer P, eds. Night and shift work. Biological and social aspects. Oxford: Pergamon Press, 1981;51-65.

Testu F. Chronopsycologie et Rythmes Scolaires. Paris: Masson, 1991.

\title{
Clossary of Chronobiology
}

Halberg F., Carandente F., Cornelissen G., Katinas G.S. 1977. Glossary of chronobiology. Chronobiologia 1977;4(suppl1): 189.

\section{Internet Sites on Chronobiology}

\author{
http:/ / www.cbt.virginia.edu/ \\ http://www.crono.icb.usp.br/ \\ http://johnsonlab.biology.vanderbilt.edu/prcatlas/prcatlas.html
}

\section{References}

ctted in the text

Andrade MMM, Benedito-Silva A, Domenice S, Arnhold, IJP, Menna-Barreto L. Sleep characteriscts of adolescents: a longitudinal study. J Adolesc Health Care $1993 ; 14: 401-6$.

Arendt J. Biological rhythms: the science of chronobiology. J R Coll Physicians Lond 1998;32(1):27-35.

Aschoff J. Zeitgeber der tierischen tagesperiodik. Naturwissnschaften 1954;41:4956.

Aschoff J. Exogenous and endogenous components in circadian rhythms. Cold Spring Harb Symp Quant Biol 1960;25:11-28.

Aschoff $\mathrm{J}$, Wever R. Human circadian rhythms: a multioscillatory system. Fed Proc $1976 ; 35: 2326-32$.

Aserinsky E, Kleitman N. A motility cycle in sleeping infants as manifested by ocular and gross bodily motility. J App Phychol 1955;8:11-8.

Bearpark HM, Michie $P$. Changes in morningness-eveningness scores during adolescence and their relation to sleep/wake disturbances. Chronobiologia $1987 ; 2: 151$. 
Boggild H, Knutsson A. Shift work, risk factors and cardiovascular disease. Scand $J$ Work Environ Health 1999;25(2):85-99.

Boyar R, Finkelstein J, Roffwang H, Kapen S, Weitzman E, Hellman L. Synchronization of augmented luteinizing hormone secretion with sleep during puberty. N Engl $\mathrm{J}$ Med $1972^{a} ; 287: 582-6$.

Boyar R, Perlow M, Hellman L, Kapen S , Weitzman E. A twenty-four hour patterns of luteinizing hormone secretions in normal men with sleep stage recording. $\mathrm{J}$ Clin Endocrinol Metab 1972 $; 35: 73-81$.

Cambrosio A , Keating P. The disciplinary stake: the case of chronobiology. Soc Study Sc $1983 ; 13: 323-53$.

Carskadon M, Harvey K, Duke P, Anders TF, Litt IF, Dement WC. Pubertal changes in daytime sleepiness. Sleep 1980;2:453-60.

Cashmore AR, Jarillo JA, Wu YJ , Liu D. Cryptochromes: blue light receptors for plants and animals. Science 1999;284(5415):760-5.

Ceolim F, Menna-Barreto L. Sleep/wake cycle and physical activity in healthy elderly people. Sleep Research Online. Colquhoun, WP 1971. Biological rhythms and human performance. London: Academic Press, 1999. (in press)

Colquhoun WP, Costa G, Folkard S, Knauth, P, editors. Shiftwork, Problems and Solutions. Peter Lang, Frankfurt/M, Berlin, Berna, New York, Paris, Viena, 1996: 224.

Copinschi G, Van Reeth O, Van Cauter E. Biologic rhythms. Nyctemeral variation in man. Presse Med 1999;28(17):936-41.

Davis FC. Ontogeny of circadian rhythms. In: Aschoff J, ed. Handbook of behavioral neurobiology. Vol 4, Biological Rhythms. New york: Plenum Press, 1981;257-74.

De Prins J , Malbecq W. Analyse spectrale pour données non équidistantes. Bull Acad Royale de Belgique 1983;69:287-94.

Eastman CI , Martin SK. How to use light and dark to produce circadian adptation to night shift work. Ann Med 1999;31(2):87-98.

Folkard S, Minors DS, Waterhourse JM. Chronobiology and shift work: current issues and trends. Chronobiologia 1985;12:31-54.

Folkard S, Monk TH. Individual differences in the circadian response to weekly rotating shift system. In: Reinberg A, Vieux N, Andlauer P, eds. Night and shiftwork: biological and social aspects. New York: Pergamon-Press, 1981;367-74.

Gaspar S, Moreno C, Menna-Barreto L Work shifts, sleep and biological rhythms. Rev Assoc Méd Bras 1998;44(3):239-45.

Gekakis N, Staknis D, Nguyen HB, Davis FC, Wilsbacher LD, King DP, Takahashi JS, Weitz CJ. Role of the CLOCK protein in the mammalian circadian mechanism. Science 1998;280(5369):1564-9.

Glass L, Mackey MC. From Clocks to Chaos. The Rhythms of Life. Princinton: Princeton University Press, 1988.

Goodwin BC. Temporal organizations and disorganization in organisms. Chronobiol Int $1997 ; 14(5): 531-6$.

Grossman VG. Defying circadian rhythm: the emergency nurse and the night shift. $J$ Emerg Nursing 1997;23(6):602-7. 
Halberg F, coordinator. Chronobiology of Human Blood Pressure. A Medtronic Seminar, G Cornélissen, Halberg E, Halberg J, Delmore P, Bakken E, Shinoda M, contrib, $2^{\text {nd }}$ ed. Minneapolis: Medtronic Inc., 1986.

Hellbrugge T. The development of circadian rhythms in infants. Cold Spring Harb Symp Quant Biol 1960;25:311-23.

Horne JA and Östberg $O$. A self-assessment questionnaire to determine morningnesseveningness in human circadian rhythms. Int $J$ Chronobiol 1976;4:97-110.

Hrushesky WJM. Circadian timing of cancer chemotherapy. Science 1985;228:7375.

Kleitman N. Biological Rhythms and Cycles. Physiol Rev 1949;29:1-30.

Krieger DT, ed. Comprehensive Endocrinology, Endocrine Rhythms. New York: Raven Press, 1979.

Manfredini R, Manfredini F, Fersini C , Conconi F. Circadian rhythms, athletic performance, and jet lag. Bri J Sports Med 1998;32(2):101-6.

Meier-Koll A. Interactions of endogenous rhythms during postnatal development: observations of behaviour and polygraphic studies in one normal infant. Int $\mathrm{J}$ Chronobiol 1979;6:179-89.

Menna-Barreto L , Benedito-Silva AA, Marques N, Andrade MMM , Louzada F. Ultradian components of the sleep/wake cycle in babies. Chronobiol Int 1993;10:103-8.

Menna-Barreto L, Benedito-Silva AA, Moreno CRC, Fischer FM, Marques N. Individual differences in night and continuously-rotating shiftwork: seeking anticipatory rather than compensatory strategy. Ergonomics 1993;36(1-3):135-40.

Miles LE, Broughton RJ, eds. Medical Monitoring in the Home and Work Environment. New york: Raven Press 1990.

Minors DS, Waterhouse JM. Mathematical and Statistical Analysis of Circadian Rhythms. Psychoneuroendocrinology 1988;13(6):443-64.

Minors DS, Waterhouse JM. Masking in humans: the problem and some attempts to solve it. Chronobiol Int 1989;6:29-53.

Monk TH, Reynolds CF, Machen MA, Kupfer DJ. Daily social rhythms in the elderly and their relationship to objectively recorded sleep. Sleep 1992;15:322-9.

Moore-Ede MC. Physiology of the circadian timing system: predictive versus active homeostasis. Am J Physiol 1986;250:R737-R752.

Moore-Ede MC, Sulzman FM. Internal Temporal Order. In: J Aschoff, ed. Handbook of behavioral neurobiology. Biological rhythms, 4. New York: Plenum Press, 1981:215-41.

Morin, LP. Serotonin and regulation of mammalian circadian rhythmicity. Ann Med 1999;31(1):12-33.

Mrozovsky N, Reebs SG, ,Honrado GI, Salmon PA. Behavioral entrainment of circadian rhythms. Experientia 1989;45:696-702.

Mrosovsky N. Rheostasis; the physiology of change. New York/Oxford: Oxford University Press, 1990.

Nelson W, Tong YL, Lee JK, Halberg F. Methods for cosinor-rhythmometry. Chronobiology 1979;6:305-23.

Parmelee AH. Sleep patterns in infancy: a study of one infant from birth to eight months of age. Acta Paediatr 1961;50:160-70. 
Plytycz B, Seljelid R. Rhythms of immunity. Arch Immunol Ther Exp (Warsz) 1997;45(23): 157-62.

Reinberg A and Smolensky MH. Biological rhythms and medicine. Cellular, metabolic, physiopathologic, and pharmacologic aspects. Topics in environmental physiology and medicine. New York: Springer-Verlag, 1983.

Richardson GS. Circadian rhythms and aging In: Schneider EL \& Rowe JW, eds. Handbook of aging. 3ed. San Diego: Academic Press, 1990.

Richter CP. Biological clocks in medicine and psychiatry. Springfield: CC Thomas, 1965.

Shanahan TL, Zeitzer JM , Czeisler CA. Resetting the melatonin rhythm with light in humans. J Biol Rhythms 1997;12(6):556-67.

Sokolov PG, Bushell WN. The chi square periodogram: its utility for analysis of circadian rhythms. J Theor Biol 1978;72:131-160.

Tomioka K, Tomioka F. Development of circadian sleep-wakefulness rhythmicity of three infants. J Interdiscip Cycle Res 1991;22:71-80.

Touitou Y, Bogdan A, Haus E, Touitou C. Modifications of circadian and circannual rhythms with aging. Exp Gerontol 1997;32(4-5):603-14.

Tsai TH, Scheving LE, Sánchez de la Peña S, Marques N, Halberg F. Circaseptan (about-7 day) modulation of circadian rhythm in corneal mitoses of Holtzman rats. Anat Rec 1989;225:181-8.

Van Cauter E, Plat L, Copinschi G. Interrelations between sleep and the somatotropic axis. Sleep 1998;21(6):553-66.

Weaver DR , Reppert SM. Direct in utero perception of light by the mammalian fetus. Dev Brain Res 1989;47:151-5.

Webb WB. Are short and long sleepers different? Psychol Rep 1979;44:259-64.

Wever RA The Circadian System of Man: Results of Experiments under Temporal Isolation. Berlin: Springer-Verlag, 1979.

Wilsbacher LD, Takahashi JS. Circadian rhythms: molecular basis of the clock. Curr Opin. Gen Dev 1998;8(5):595-602. 
